International Journal of English Literature and Social Sciences
Vol-6, Issue-1; Jan-Feb, 2021

\title{
The Existence of Vita Solo Volleyball Club
}

\author{
Edwin Taufik Hidayat ${ }^{1, *}$, Agus Kristiyanto $^{2}$, Slamet Riyadi ${ }^{3}$
}

\author{
${ }^{1}$ Department of Sports Science, Postgraduate Program, SebelasMaret University (UNS), Indonesia \\ 2,3Jalan Ir. Sutami No. 36A, Jebres, Kota Surakarta, Central Java, post code:57126, Indonesia. \\ *Corresponding Author
}

Received: 03 Nov 2020; Received in revised form: 24 Jan 2021; Accepted: 11 Feb 2021; Available online: 28 Feb 2021 (C)2021 The Author(s). Published by Infogain Publication. This is an open access article under the CC BY license (https://creativecommons.org/licenses/by/4.0/).

\begin{abstract}
This research aims to (1) explore in detail the existence of the VITA Solo volleyball club (2) to describe in detail the Human Resources at the VITA Solo volleyball club (3) to describe in detail the background and objectives of coaching VITA Solo volleyball club athletes. (4) to describe in detail the management of the VITA Solo volleyball club (5) to describe in detail the types of awards for outstanding athletes at the VITA Solo volleyball club. The research method used is descriptive qualitative. Research subjects came from administrators, coaches, athletes and alumni of players at the VITA Solo volleyball club. Sources of research data were obtained from person, paper, and place. Observation, interview, and documentation were used as the techniques of data collection. Based on the research that has been carried out, the results show that HR, Coaching, Training Programs, Funding, and Club Achievements are stated very well.
\end{abstract}

Keywords-Sports, Volleyball, Management.

\section{INTRODUCTION}

Volleyball is one of the most popular sports in Indonesia. The popularity of volleyball is marked by the development of various local clubs, from amateur to professional clubs. Volleyball is a sport that is very popular with the community, from children to adults, both men and women, from villages to cities. The high public interest in volleyball can be seen from the number of private television stations in Indonesia that broadcast national volleyball matches.In addition, corporations and private educational institutions and government owned clubs begin to see volleyball as a promising media campaign in Indonesia.

The existence of volleyball today is starting to come in and blend in with people's lives in various aspects, such as the social aspect that makes the local club as one of the regional identities. In other aspects such as the economy of volleyball championships both on a regional to national scale can drive the economic activities of local communities such as the sale of food, beverages, merchandise, parking services, to ticketing. The high public interest in playing volleyball has a positive impact on the Indonesian volleyball national team. One of the positive impacts for the national team is the development of the achievements of the Indonesian national team at the international level, namely being able to show their achievements by winning the SEA Games in 2008 and 2019. In 2018 the Indonesian men's volleyball national team came out as champions in the Lienvietpostbank Cup International volleyball championship in $\mathrm{Ha} \mathrm{Nam}$, Vietnam.

The National Volleyball Federation of Indonesia (PBVSI) strives to create an independent and accomplished volleyball. One of the steps taken is holding a championship which is held annually which is participated by clubs from all over Indonesia.The championship is divided into two divisions, the first is the main division Livoli and the one above it is the Indonesian Volleyball League or better known as LIVOLI. In addition, there is a national tournament held by PBVSI in collaboration with a sponsor, namely PROLIGA, which presents professional clubs in Indonesia.

The emergence of amateur and professional volleyball clubs shows that the sport is starting to be favored by the public. One of the amateur clubs in Surakarta is VITA Solo which still exists today.VITA Solo 
was founded in the 1950 s by Haryono with the aim of developing novice volleyball athletes in Solo and fostering interest in the community, especially in Solo and its surroundings towards volleyball.

VITA Solo as one of the oldest amateur clubs in Surakarta. It is one of the most calculated clubs in the Central Java region, and is one of the contributors to volleyball athletes who compete in national and PROLIGA events which are filled with professional volleyball clubs Indonesia.VITA Solo strives to do coaching in various ways, one of which is by dividing it into several levels, namely; beginners, juniors and seniors. This has been continuous until now and is able to print athletes to maintain the achievements of Surakarta club and volleyball.VITA Solo in PON 2012 and PON 2020 sent its target athletes to represent.

Central Java in PON Riau and PON Papua, and it is proven that in 2012 the women's volleyball squad in Central Java which competed in PON Riau 90\% came from the VITA Solo volleyball club and the Central Java volleyball contingent won 3rd place.This proves that the athletes trained by VITA Solo have a very calculated ability in national football. In the last 10 years, VITA Solo still exists to participate in regional and national championships, including the following:

Table 1. National Championships

\begin{tabular}{|l|l|l|l|}
\hline Year & \multicolumn{1}{|c|}{ List of Championship } & \multicolumn{1}{|c|}{ Place } & \multicolumn{1}{|c|}{ Achievement } \\
\hline 2009 & PORPROV Putra & Surakarta & $2^{\text {nd }}$ Winner \\
\hline 2009 & PORPROV Putri & Surakarta & $1^{\text {st }}$ Winner \\
\hline 2011 & Pra PON Putri & Sentul, Bogor & $4^{\text {th }}$ Winner \\
\hline 2012 & PON Putri & Riau & $3^{\text {rd }}$ Winner \\
\hline 2013 & LIVOLI Divisi I Putri & Banyuwangi & $2^{\text {nd }}$ Winner \\
\hline 2014 & LIVOLI DivisiUtamaPutri & Bandung & - \\
\hline 2014 & PORPROV Putra & Purwokerto & $2^{\text {nd }}$ Winner \\
\hline 2014 & PORPROV Putri & Purwokerto & $1^{\text {st }}$ Winner \\
\hline 2015 & LIVOLI Divisi I Putri & Bali & - \\
\hline 2016 & LIVOLI Divisi I Putri & Ungaran, Semarang & $2^{\text {nd }}$ Winner \\
\hline 2017 & LIVOLI DivisiUtamaPutri & Tangerang & - \\
\hline 2018 & PORPROV Putri & Boyolali & $2^{\text {nd }}$ Winner \\
\hline 2018 & LIVOLI Divisi I Putri & Tangerang & $1^{\text {st }}$ Winner \\
\hline 2019 & LIVOLI DivisiUtamaPutri & Tangerang & - \\
\hline 2019 & Pra PON & Jakarta & $2^{\text {nd }}$ Winner \\
\hline
\end{tabular}

With the huge potential that is owned by VITA Solo, it is an added and positive value for the club so that it can progress and develop. This is evidenced by VITA Solo competing at the national level, namely the Volleyball National Championship and LIVOLI. In participating in the competition, VITA Solo uses $100 \%$ of its own trained athletes, and in the LIVOLI competition, VITA Solo is one of the amateur clubs participating and is able to penetrate regional and national championships among the professional volleyball clubs that follow it.Therefore, it is the duty of all club members from the ranks of coaches and players to pay attention to this, because the achievements achieved are one of the main factors in seeing whether the club exists or not.
On the other hand, the management and coach of the VITA Solo volleyball club itself must think harder because currently sports clubs in Indonesia are required to be more independent in participating in competitions every year.So far, VITA Solo has relied heavily on KONI through PBVSI in Surakarta, so management is required to be more creative in managing club finances to participate in every championship that the VITA Solo club participates in.

In the VITA Solo volleyball club, various levels of age and education are distinguished in their coaching. This aims to make the athlete's training method more effective and more efficient, which is carried out by the ranks of coaches and that the regeneration of athletes can 
run well.The coaching carried out by the ranks of coaches is routine and takes advantage of the current sophistication of science and technology to see professional volleyball club exercises that can be applied to training at VITA Solo from various age groups. In addition, coaches and players also use Facebook, Instagram and Twitter to further introduce the VITA Solo volleyball club so that it is better known to the wider community, not only in Solo and its surroundings, with the aim that players who already have good skills can attract government agencies to using the services of players trained by the VITA Solo volleyball club so that a mutually beneficial cooperation contract will be established for both parties.

From the background described above, What needs to be studied in this research is a model of athlete recruitment, coaching, promotion, funding and awards for volleyball athletes VITA Solowith the aim of this volleyball club being able and still to exist in the national championship by creating talented and quality athletes who are able to penetrate professional and national volleyball teams in order to achieve maximum performance.

\section{METHOD}

This study used a qualitative research approach;the researchers used a descriptive type.Zainal arifin (2011) stated that descriptive research is a study used to decrypt and answer the problems of a phenomenon or event that occurs today, whether about phenomena in a single variable or correlation and or a comparison of various variables, while Donald Ary (2010) in Introduction to Research In Education revealed that "Qualitative research is a generic term for a variety of research approaches that study phenomena in their natural setting, without predetermined hypotheses". Qualitative Reaseach research is aimed at describing and analyzing phenomenon.

Qualitative research was chosen because of the stability of the researcher based on his research experience and qualitative methods can provide more complex details about phenomena that are difficult to reveal by quantitative methods. The data generated from this research are in the form of writings, words and documents that come from sources or informants who are researched and can be trusted. In Moleong's book (2007) there are several other opinions in defining qualitative research, including according to Denzin and Lincoln, which states that qualitative research is research that uses a natural background, with the intention of interpreting phenomena that occur and are carried out by involving various methods that exist in qualitative research. The methods commonly used are interviews, observation, and use of documents.

From these studies, it can be concluded that qualitative research describes the data collected in the form of words, pictures and not numbers. Data derived from interviews, observations and documentation are then described so that they can provide clarity on the focus discussed.

According to Arikunto (2006) the source of data in research is the subject from which data can be obtained. In general, sources can be classified into three types, namely person, paper or document, and place. Sources of person data are part of the committee, coaches and athletes. Sources of paper data are documents, documents related to the VITA Solo volleyball club.The data source of the research place was conducted at the VITA Solo volleyball club.

According John W. Cresweel (2007) "The data collection in case study research is typically extensive, drawing on multiple sources of information, such as observations, interviews, documentations and audiovisual materials". Interview, observation and documentatio were used as data collection techniques in the study. Data analysis techniques are a very important part of research because data analysis can provide meaning and it is useful in solving problems in the research. The collected data were then analyzed.The analysis techniques used in this study are as follows:

1. Data collection, which is the collection of all the data that has been obtained.

2. Data reduction and information on recruitment, coaching, promotion, funding and awarding models for athletes at the VITA Solo volleyball club.

3. Data display, data classification or systematic summary of research data.

4. Drawing conclusions and verification, with the amount of data obtained so that it will support a conclusion in the study.

\section{RESULT AND DISCUSSION}

\section{A. The History of VITA Solo Volleyball Club}

It was founded in 1950 by two initiators, Mr. Haryono and Mr. Heri with the aim of developing the seeds for volleyball athletes in the city of Solo and its surroundings, as well as fostering interest in the community, especially in the city of Solo and its surroundings towards volleyball, because at that time volleyball was relatively new in Indonesia.At the beginning of its formation, the VITA Solo volleyball club for training was located in Mangkunegaraan and 
always moved places, until finally having a permanent training ground in Penumping, Laweyan. The founders adopted the "sincere" system, the meaning of the sincere system is to sincerely provide knowledge, spend time, provide training, and pass on experiences to all people who want to practice volleyball at the VITA Solo club. These principles have always been maintained by the current club management.Although, VITA Solo is an amateur volleyball club and adheres to a sincere system, the coaching process carried out is always based on scientific methods and professionalism. For this reason, collaboration with various parties is carried out starting from the selection of athletes, the training process, and competitions to maintain the viability of the VITA Solo volleyball club so that it is not eroded by the times in the midst of many professional volleyball clubs.

1. Organizational Structure

The management of the VITA Solo volleyball club consists of advisors, general chairman, secretary, treasurer and sections. The following is the management structure of the VITA Solo volleyball club:

Table 2. Organizational Structure

\begin{tabular}{|c|c|}
\hline Position & Name \\
\hline Advisors & $\begin{array}{l}\text { 1. } \text { FX. HadiRudiatmo } \\
\text { 2. BambangTukoWibowo S } \\
\text { 3. Haryanto Tri Putranto }\end{array}$ \\
\hline $\begin{array}{l}\text { General } \\
\text { Chairman }\end{array}$ & Drs. AgusSuyanto \\
\hline Secretaries & $\begin{array}{l}\text { 1. } \text { Budi Mohamad } \\
\text { RondhaniArdhiansyah } \\
\text { 2. SiswiPurno, S.Pd. }\end{array}$ \\
\hline Treasures & $\begin{array}{l}\text { 1. DanangSugiarto, S.Pd. } \\
\text { 2. Musta'inWibowo }\end{array}$ \\
\hline $\begin{array}{l}\text { Equipment } \\
\text { section }\end{array}$ & $\begin{array}{l}\text { 1. Suparno } \\
\text { 2. Mochammad Sri Rahardjo, } \\
\text { S.H. } \\
\text { 3. Joko Suwondo }\end{array}$ \\
\hline $\begin{array}{l}\text { Funding } \\
\text { section }\end{array}$ & $\begin{array}{ll}\text { 1. } & \text { Mufid } \\
\text { 2. } & \text { Sri NurDwiHastuti }\end{array}$ \\
\hline Member & $\begin{array}{l}\text { All players,coaches and club } \\
\text { administrators, as well as } \\
\text { supported by volleyball athletes } \\
\text { who graduated from VITA Solo. }\end{array}$ \\
\hline
\end{tabular}

2. Bylaws (AD/ART)
The bylaws used by the VITA Solo volleyball club is a system of sincerity and mutual cooperation based on PANCASILA and the 1945 Constitution as a basis and work guideline in enhancing the dignity, glory of the nation and state of Indonesia.

3. The expenditure budget

The expenditure budget needed must be in accordance with existing funds, for that the management is always active so that the available funds can support all the needs for daily training, the source of funds obtained by the management is obtained from PBVSI funds, KONI, grants / donations from alumni of VITA athletes Solo, who is already successful in his career and from the transfer fee of a professional volleyball club who uses the services of VITA Solo educated players to compete in the Proliga volleyball competition.

The funds collected are used for:

a. Procurement and repair of volleyball facilities and infrastructure

b. Accommodation follows official volleyball championships which are held outside the region.

4. The work program

The work plan or work program carried out by the VITA Solo volleyball club, namely:

a. Perform daily exercise activities according to an exercise schedule

b. Implement a short and long term exercise program

c. Conducting selection of athletes at various age levels / school levels

d. Doing additional training to enter a championship

e. Participate in regional or national championship events to increase your competitive experience

f. Send high-achieving athletes to participate in or be contracted by professional volleyball clubs

\section{B. Human Resources}

1. Recruitment and Quality of Coaches

The coach recruitment was carried out by the VITA Solo volleyball club by asking for help from several alumni athletes who graduated from VITA Solo who were accomplished and experienced. The alumni of VITA Solo who were originally asked to help train feel that they also have the VITA Solo club which has raised its 
name, thus creating a sense of responsibility to the club and VITA Solo students.

Based on research conducted at the VITA Solo volleyball club, coaches with quality and experience in competing, coaches who have no doubt defended PORDA, PON or Proliga team. Because the VITA Solo volleyball club coaches have regional and national licenses, the coaches are familiar with the training system and run a planned training program and have a professional attitude, high discipline and assertiveness towards the athletes.The coaches also have high loyalty, responsibility and dedication to the club and their students, because as an amateur volleyball club, the coaches from VITA Solo also did not get a monthly salary or allowance.

2. Recruitment and Quality of Athletes

The recruitment of athletes at the VITA Solo volleyball club is carried out at several levels, starting from elementary school, junior high school, high school or senior who are prepared to take part in competitions. The recruitment of athletes is free of charge, because VITA Solo is an amateur club that is trusted by the people of Solo and its surroundings to foster and train children to excel in volleyball.

Based on the results of the research that has been done, the quality of VITA Solo athletes is very good, this is evidenced by the achievements obtained by athletes at several age levels.

\section{Coaching}

1. The implementat of activities

The implementation of coaching carried out by the VITA Solo volleyball club is carried out through several levels ranging from recruiting athletes of various ages, nurseries, scouting athletes' talents. The implementation is as follows:

a. Recruitment

Recruiting athletes of various ages, then entry into beginners, then selected to enter the junior to the senior stage.

b. Coaching

Conducting coaching from the child / beginner level to get talented and potential athletes, who are then trained, nurtured and further developed to become good and quality athletes so that they are able to play and compete to join a professional volleyball club.

c. The scouting of talent
The scouting of talent at the VITA Solo volleyball club is through the coordination of the coaches with the assistant coaches, while the scouting is emphasized as follows:

1) Adjustment of height and weight

2) Increased mobility

3) Control of character, personality, intelligence, emotions and motivation

4) Increasing skills and specific technical capabilities mastered

2. The training programs

The training programs provided at VITA Solo Volleyball Club include short, medium and long term training programs. Based on research conducted by VITA Solo volleyball club, the training program carried out is a long-term program.

In the long-term (annual) training program there are things that must be prepared for the players, namely:
a. Physical strength
b. Techniques and Tactics
c. Mental power
d. Teamwork
e. Degree of experiences

3. Facilities and Infrastructure

The facilities and infrastructure that is owned to support and facilitate the implementation of the organization and training of the VITA Solo volleyball club are a secretariat office and the facilities to support the implementation of training activities at the VITA Solo volleyball club are presented in table form.

Table 3.VITA Solo volleyball club training equipment

\begin{tabular}{|c|l|l|l|}
\hline No & Equipments & $\begin{array}{l}\text { Amoun } \\
\mathrm{t}\end{array}$ & $\begin{array}{l}\text { Conditi } \\
\text { on }\end{array}$ \\
\hline 1 & Ball & 23 & Good \\
\hline 2 & Net & 3 & Good \\
\hline 3 & Net Poles & 2 & Good \\
\hline 4 & Ball Basket & 1 & Good \\
\hline 5 & Antenna/rods & 4 & Good \\
\hline 6 & Referee chair & 1 & Good \\
\hline 7 & Bench press & 2 & Good \\
\hline 8 & Jump goal & 10 & Good \\
\hline 9 & Cones & 10 & Good \\
\hline
\end{tabular}


4. Achievement

The following are some of the achievements obtained by VITA Solo volleyball athletes at the senior level both men and women in the last 10 years:

Table 4. Achievments

\begin{tabular}{|l|l|l|l|}
\hline Year & \multicolumn{1}{|c|}{ List of Championships } & \multicolumn{1}{|c|}{ Place } & \multicolumn{1}{|c|}{ Achievement } \\
\hline 2009 & PORPROV Putra & Surakarta & $2^{\text {nd }}$ Winner \\
\hline 2009 & PORPROV Putri & Surakarta & $1^{\text {st }}$ Winner \\
\hline 2011 & Pra PON Putri & Sentul, Bogor & $4^{\text {th }}$ Winner \\
\hline 2012 & PON Putri & Riau & $3^{\text {rd }}$ Winner \\
\hline 2013 & LIVOLI Divisi I Putri & Banyuwangi & $2^{\text {nd }}$ Winner \\
\hline 2014 & LIVOLI DivisiUtamaPutri & Bandung & - \\
\hline 2014 & PORPROV Putra & Purwokerto & $2^{\text {nd }}$ Winner \\
\hline 2014 & PORPROV Putri & Purwokerto & $1^{\text {st }}$ Winner \\
\hline 2015 & LIVOLI Divisi I Putri & Bali & - \\
\hline 2016 & LIVOLI Divisi I Putri & Ungaran, Semarang & $2^{\text {nd }}$ Winner \\
\hline 2017 & LIVOLI DivisiUtamaPutri & Tangerang & - \\
\hline 2018 & PORPROV Putri & Boyolali & $2^{\text {nd }}$ Winner \\
\hline 2018 & LIVOLI Divisi I Putri & Tangerang & $1^{\text {st }}$ Winner \\
\hline 2019 & LIVOLI DivisiUtamaPutri & Taangerang & - \\
\hline 2019 & Pra PON & Jakarta & $2^{\text {nd }}$ Winner \\
\hline
\end{tabular}

\section{Funding}

Funding for the VITA Solo volleyball club to maintain its existence is obtained from:

1. Government Funds

The annual budget issued by government of Surakarta through KONI is received by PBVSI Surakarta for the development of volleyball athletes. The funds are fully used for the needs of facilities and infrastructure and other supporting needs

2. Sponsorship Funds

Funds are obtained from sports players and from regional companies that have an interest in sports, especially volleyball, besides that sponsorship is also obtained from good relationships between colleagues and professional volleyball club players who use the services of athletes trained by the VITA Solo volleyball club.

3. Grants / Assistance Funds

The grant funds obtained by the VITA Solo volleyball club come from very generous management who have high loyalty to the VITA Solo volleyball club, besides that, grants are also obtained from alumni of VITA Solo athletes who have been successful in their careers, because they realize that that the VITA Solo volleyball club is a bridge to the success of their careers.

\section{E. Athlete awards}

VITA Solo volleyball club awards that can be given to athletes with achievements, namely:

1. Material

The material is in the form of direct cash, where the cash is obtained from the championships they are participating in, both regional championships and national championships. The cash obtained from the championships that are participating will be distributed directly to athletes in a fair, clear and transparent manner.

2. Non-material

Non-material means that VITA Solo volleyball athletes who have achievements, those who are teenagers will be channeled or even taken by professional volleyball clubs, and for adulthood they will be channeled even to be taken by BUMD, BUMN or become state servants such as , police, TNI and others. Therefore, there is good cooperation between VITA Solo and companies that want to recruit athletes from the VITA Solo volleyball club. 


\section{CONCLUSION}

Based on the discussion of the Basic Interpretive Study on HR, Coaching, Promotion, Funding and Awards for Athletes at Volleyball Club VITA Solo, it can be concluded as follows:

1. The organization at the VITA Solo volleyball club is good, because the elements contained in the organization are running well according to their functions and positions.

2. Human resources at the VITA Solo volleyball club are good because they consist of professional administrators who have been active in volleyball for a long time and understand volleyball, the coaches also have volleyball coaching licenses both regional and national, while the athletes also have dedication, loyalty and high discipline in order to be able to lift the achievements of the VITA Solo volleyball club.

3. The coaching method available at the VITA Solo volleyball club is good because the coach and management always carry out coaching which is always carried out covering all areas, both from learning achievements and in the field. The trainers and administrators also carried out changes in providing methods and patterns of coaching, not only the old programs. Then VITA Solo athletes also have discipline, high motivation to get more achievements.

4. Promotion carried out by the VITA Solo volleyball club is good, because it is able to keep up with developments in science and technology.

5. VITA Solo volleyball club funding is good, although as an amateur club the administrators are able to use limited funds in an efficient and effective manner, besides that the management and coach also think long and ahead so that the VITA Solo club can continue to exist today.

6. Athlete awards for VITA Solo volleyball club is sufficient, it can be seen the reward given while only for outstanding athletes, Meanwhile, for athletes who have not performed well but have good quality, volleyball club VITA Solo has not thought about it.

\section{ACKNOWLEDGEMENT}

The author would like to thank AgusKristiyanto and SlametRiyadi as my supervisors for their guidences. The author also thanks Eko Ari Anto for checking the article that greatly improved the manuscript.

\section{REFERENCES}

[1] Arifin, Zainal. 2011. PenelitianPendidikan: Metodedan Paradigma Baru. Bandung: PT. RemajaRosdakarya

[2] Arikunto, Suharsimi. 2006. Prosedur Penelitian Suatu Pendeketan Praktek, Edisis Revisi VI. Jakarta: RinekaCipta.

[3] Ary, Donald. 2010. Introduction to Research In Education. United States: Wadsworth Cengage Learning.

[4] Creswell W. John. 2007. Qualitative Inquiry and Research Design Choosing Among Five Approaches, California: SagePublications.

[5] Moleong, Lexy J. 2007. Metodologi Penelitian Kualitatif, Bandung: PT Remaja Rosdakarya Offset 